\title{
THE INFLUENCE OF DifFERENT INFILl STRUCTURES ON THE MEChaNiCAL Properties in AdDitive ManUfaCtURing
}

\author{
Wolfgang Förster ${ }^{1}$; Thomas Pucklitzsch $^{2}$; Daniela Nickel ${ }^{3}$ \\ Berufsakademie Sachsen, Staatliche Studienakademie Glauchau, Industrielle Produktion, \\ Kopernikusstraße 51, 08371 Glauchau, Germany \\ e-mail: ${ }^{1}$ wolfgang.foerster@ba-sachsen.de; ${ }^{2}$ thomas.pucklitzsch@ba-sachsen.de; \\ 3. daniela.nickel@ba-sachsen.de
}

\begin{abstract}
Besides the outer shell, it is the internal structures that contribute the most to the mechanical integrity of an additively manufactured component. In order to investigate the influence of the geometrically different internal structures and infill density on the Young's modulus, tensile strength and failure strain, tensile specimens of polylactic Acid (PLA) were prepared using fused deposition modeling and tested at room temperature. There was a significant influence of the infill density, the manufacturing process and the resulting microstructure on the mechanical properties. In summary, the position of the microstructure relative to the load direction is found to be a significant factor of influence.
\end{abstract}

\section{Keywords}

Fused deposition modeling; PLA; Infill; Tensile test; Mechanical properties; Microstructure.

\section{Introduction}

Nature follows the principle of "as much as necessary, as little as possible". This approach ensures optimum properties while being energy- and resource-efficient at the same time. It is therefore hardly surprising that engineers try to transfer this principle to the world of technology. Components are to be as light as possible and still have excellent mechanical properties. Bones are a good example of how this works in nature. They consist of a shell, which provides a functional surface, and an internal structure, which is porous in design. Additive manufacturing can be used to artificially produce such complex components and (internal) structures. A widely used technique is the fused deposition modeling (FDM). Due to its simple design and robust functionality, it is frequently used in the field of plastics. As the print head moves, a plastic wire (filament) is conveyed from a roll to the print head, where it is melted and extruded through a nozzle. This procedure was also used for the present study. Since the internal structures determine both the mechanical integrity and the weight of the component, they offer potential for optimization. A variety of different internal structures is available for this purpose. However, which structures are suitable, and how can they be created? How do they affect the mechanical properties? Is there an optimum?

These and similar questions have already been investigated by researchers. Corresponding analyses have investigated the influence of manufacturing parameters such as layer thickness, infill density or infill structures on the mechanical properties. They included tensile tests with samples made of polylactide Acid (PLA). Low layer thicknesses resulted in higher tensile and flexural strengths while higher layer thicknesses raise both the Young's modulus and the ductility [1, 2]. Higher infill density also increases tensile strength and stiffness $[3,4,5,6]$. The influence of the infill structures, on the other hand, can be considered minor [7, 8]. Further production parameters such as direction of production, layer thickness, printing 
temperature and filament feed rate only have a slight mutual impact and therefore cannot be separated from each other $[9,1,3,10]$.

\section{$1 \quad$ Research Subject}

Previously published studies show an effect on mechanical properties; however, they lack a rationale for their observations. Our investigations are intended to provide information about possible causes. To ensure comparability, we are also using tensile tests with samples made of PLA as well as fused deposition modeling as an additive manufacturing process.

\section{Experimental Investigations}

\subsection{Specimens Preparation}

Tensile testing was used to provide easy access to the measurement of the mechanical properties. For this purpose, flat tensile specimens of shape $1 \mathrm{~B}$ according to DIN EN ISO 527-2 were used, which has the advantage that the specimens can be reproducibly fabricated using fused deposition modeling. In addition, tensile stresses are significant contributors to component failures.

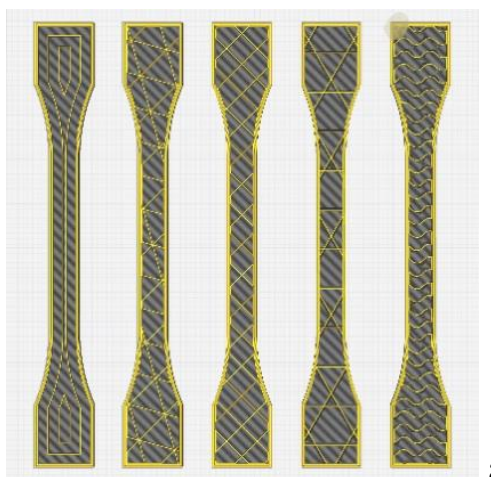

Source: Own work a)

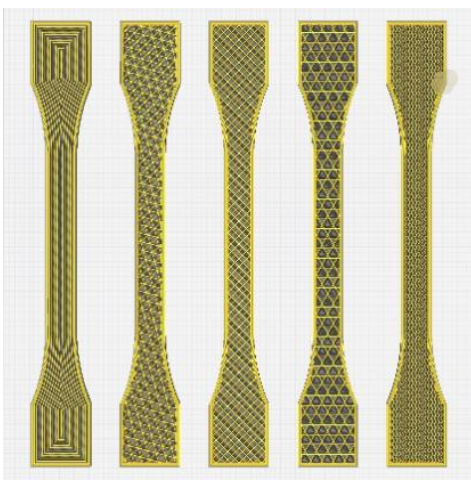

b)
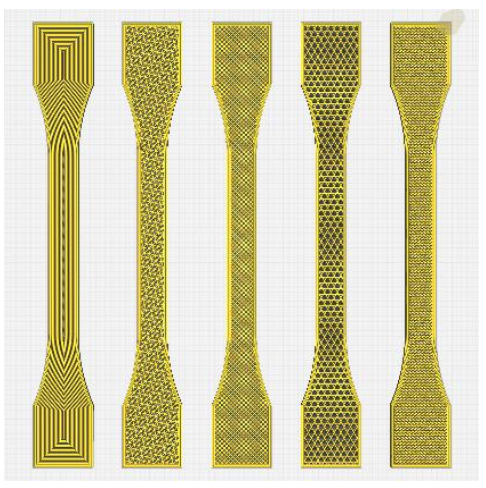

c)

Fig. 1: Sectional view of the used flat tensile specimens in the slicer software CURA for an infill density of a) 10\%, b) $40 \%$ and c) $70 \%$. The structures used, in each case from left to right: concentric, triangles, grid, cubic subdivision and gyroid

In order to investigate whether and how the mechanical properties are influenced by different infill structures, the slicer software CURA was used to select five infill structures which differ from each other to as great an extent as possible. The slicer is an important and necessary tool in the field of additive manufacturing. It breaks down the digital model of the object to be produced into individual layers. This information is then passed on to the $3 \mathrm{D}$ printer and scanned by the print head. The slicer also calculates the most efficient way to deposit the print material in the right positions within a layer. All print parameters and infill structures can be adjusted here. This produces the layered structure characteristic of additive manufacturing. The selected infill structures range from simple lines to 2D structures and more complex three-dimensional structures. Since the interaction between the shell and the infill structure is always decisive for mechanical stability of an additively manufactured component, the tensile specimens are also coated with a shell of $1 \mathrm{~mm}$ thickness. In addition to the structures, their infill densities were also varied. The infill density is the percentage to which the specimen volume is filled with material. This ranged from $0 \%$ - i.e. hollow specimens - to a $10 \%, 40 \%$, $70 \%$ and $100 \%$ infill. Figure 1 shows the sectional view of the tensile specimens with the infill structures used and an infill density of $40 \%$ in the slicer software. 
For statistical validation, each configuration included at least three tests. The specimens were fabricated by fused deposition modeling on a commercial ULTIMAKER S5 3D printer, with five specimens fabricated at a time as shown in Figure 1. Table 1 summarizes important manufacturing parameters. A standard polylactide Acid filament from the manufacturer FormFutura was used as a material.

Tab. 1: Overview of used manufacturing parameters, infill densities and infill structures.

\begin{tabular}{|l|l|}
\hline Infill Pattern & Gyroid, Concentric, Triangles, Grid, Cubic Subdivision \\
\hline Infill Density & $0 \%, 10 \%, 40 \%, 70 \%, 100 \%$ \\
\hline Nozzle Diameter & $0.4 \mathrm{~mm}$ \\
\hline Print Temperature & $200^{\circ} \mathrm{C}$ \\
\hline Print Speed & $50 \mathrm{~mm} / \mathrm{s}$ \\
\hline Layer Height & $0.1 \mathrm{~mm}$ \\
\hline Wall Thickness & $1 \mathrm{~mm}$ \\
\hline Line Width & $0.3 \mathrm{~mm}$ \\
\hline
\end{tabular}

Source: Own

\subsection{Experimental Procedure}

The tensile tests were performed in-house on a TIRA 28100 tension/compression testing machine at room temperature. Prior to the test, the tensile specimens were stored for at least 24 hours in a climatic cabinet at constant temperature and humidity and only removed, weighed and clamped in the testing machine immediately before the start of the test. The tests were load-controlled at a traverse speed of $1 \mathrm{~mm} / \mathrm{min}$. To ensure the most accurate determination of the Young's modulus, the displacement was measured with an extensometer at the beginning of the test and removed again at 5\% strain upon indication by the testing software. The test was terminated either when the specimen broke or when the force dropped to $80 \%$ of the maximum load.

\section{$3 \quad$ Results and Discussion}

\subsection{Correction Factor}

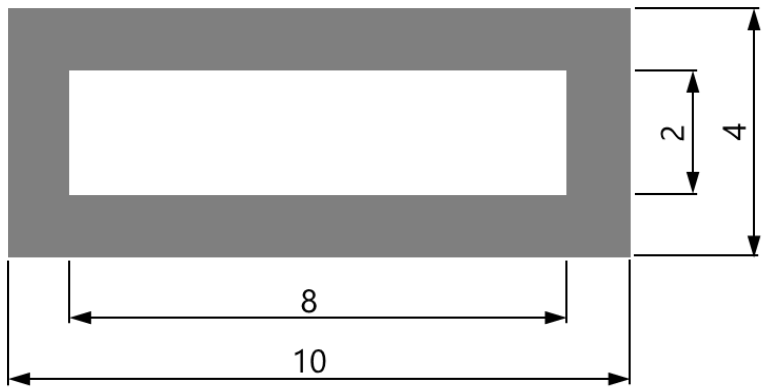

Source: Own

Fig. 2: Schematic view of the cross-section of a hollow specimen with the corresponding dimensions

The force and displacement data measured in the tensile tests are used to calculate the requested parameters such as the Young's modulus or tensile strength. In the classic tensile test, the cross-sectional area of the tested specimens is also significant as it influences the 
magnitude of the occurring stresses. A homogeneous area is assumed, which would correspond to a rectangle of a 10x4 mm2 area as shown in Figure 2.

In this test, however, the infill densities were specifically varied, which results in a reduced underlying cross-sectional area as a function of the infill density. This circumstance must also be considered when calculating the mechanical parameters. For this purpose, a correction factor $m_{\text {specific }}$ in dependence of the specimen mass was used since the weight equally drops with decreasing infill densities. Thus, the correction factor is calculated from the ratio of the specimen mass with an infill density lower than $100 \%$ to the mass of specimens with a $100 \%$ infill density. For a hollow specimen, as shown in Figure 2, the correction factor is calculated to be 0.6 , which means that the weight of the hollow specimen is approximately $60 \%$ of the weight of a solid specimen.

(weight of solid specimen)

$$
\begin{gathered}
m_{0}=10,5111 g \\
m=6,4085 g
\end{gathered}
$$

(weight of hollow specimen)

$$
m_{\text {specific }}=\frac{g}{g_{0}}=\frac{6,4085 \mathrm{~g}}{10,5111 \mathrm{~g}}=0,6097 \triangleq \underline{\underline{60 \%}}
$$

The accuracy of this assumption is shown by comparison with the percentage of the remaining cross-section for the hollow specimen. Correspondingly, it amounts to $60 \%$ of the cross-sectional area of a solid specimen.

$$
\begin{gathered}
\text { (area of frame) } \quad A_{\text {frame }}=10 \mathrm{~mm} \cdot 4 \mathrm{~mm}-8 \mathrm{~mm} \cdot 2 \mathrm{~mm}=\underline{24 \mathrm{~mm}^{2}} \\
\text { Proportion }_{\text {frame }}=\frac{24 \mathrm{~mm}^{2}}{10 \mathrm{~mm} \cdot 4 \mathrm{~mm}}=0,6 \triangleq \underline{\underline{60 \%}}
\end{gathered}
$$

To calculate the (specific) mechanical properties depending on the infill density, the Young's modulus and tensile strength were multiplied by the correction factor $m_{\text {specific }}$ as both parameters are directly dependent on the cross-sectional area. For a qualitative classification, the results are compared with the values from the manufacturer's data sheet.

\subsection{Mechanical Properties}

Figure 3 shows the diagrams containing the average values for the Young's modulus, tensile strength and failure strain.

\subsubsection{Specific Young's Modulus}

The Young's modulus is a material parameter that characterizes the resistance to reversible deformation. It is a measure of a material's stiffness.

As expected, the lowest value for the Young's modulus is obtained for the hollow specimen, i.e. with a $0 \%$ infill density. The values for the Young's modulus rise linearly with increasing infill densities. This behavior can be observed in all the infill structures under investigation. A closer examination of the identical infill densities of the different structures shows that the differences become more pronounced as the infill density increases. At an infill density of $10 \%$, the values are almost equal; at $40 \%$ and $70 \%$, the values are noticeably higher, especially for the concentric structure.

In comparison with the manufacturer's data sheet for the PLA used, the values of the specimens with a $100 \%$ infill density are slightly above the specified values. However, the higher dispersion must also be considered here. Furthermore, the values are only comparable 
to a limited extent since the specifications from the data sheet refer to injection-molded specimens. These have a homogeneous microstructure in contrast to the additively manufactured specimens, which exhibit an inhomogeneous microstructure resulting from the layered structure.

In addition, the Young's modulus is by definition a characteristic material parameter that is determined on homogeneous (pore-free) specimens. If, due to pores or other structures, the microstructure deviates from this state, the Young's modulus becomes structure-dependent. It thus rather constitutes a parameter of the overall structure than that of the material. Therefore, only the values for the specimens with a $100 \%$ infill density are comparable.
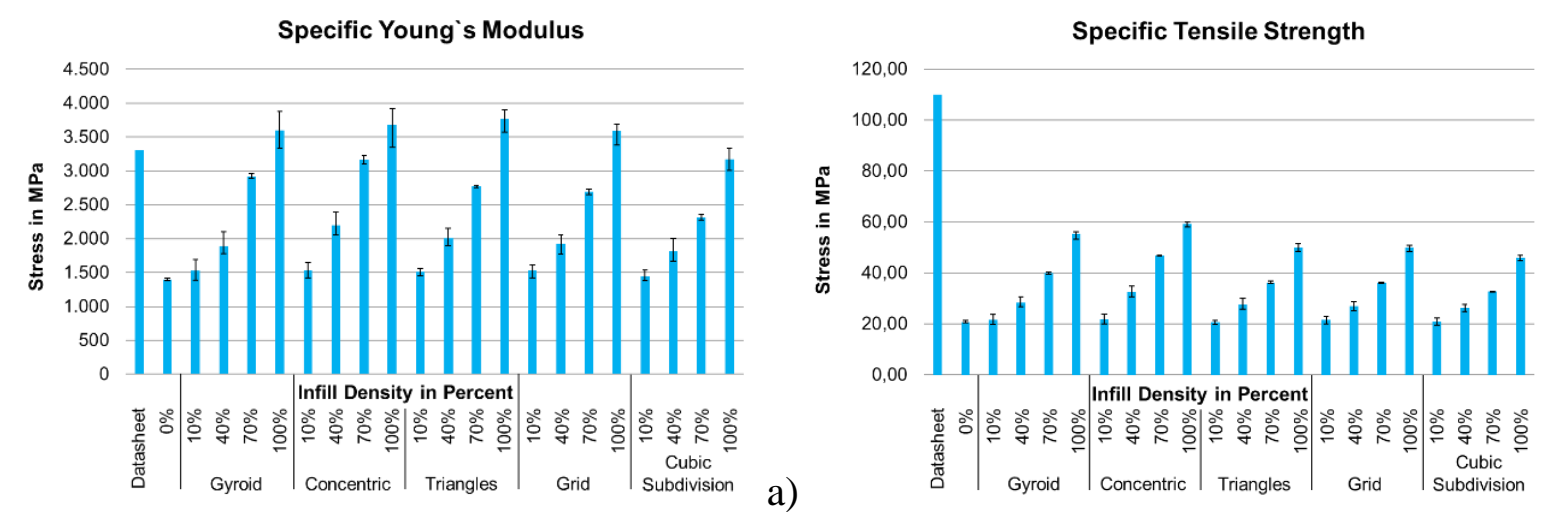

b)
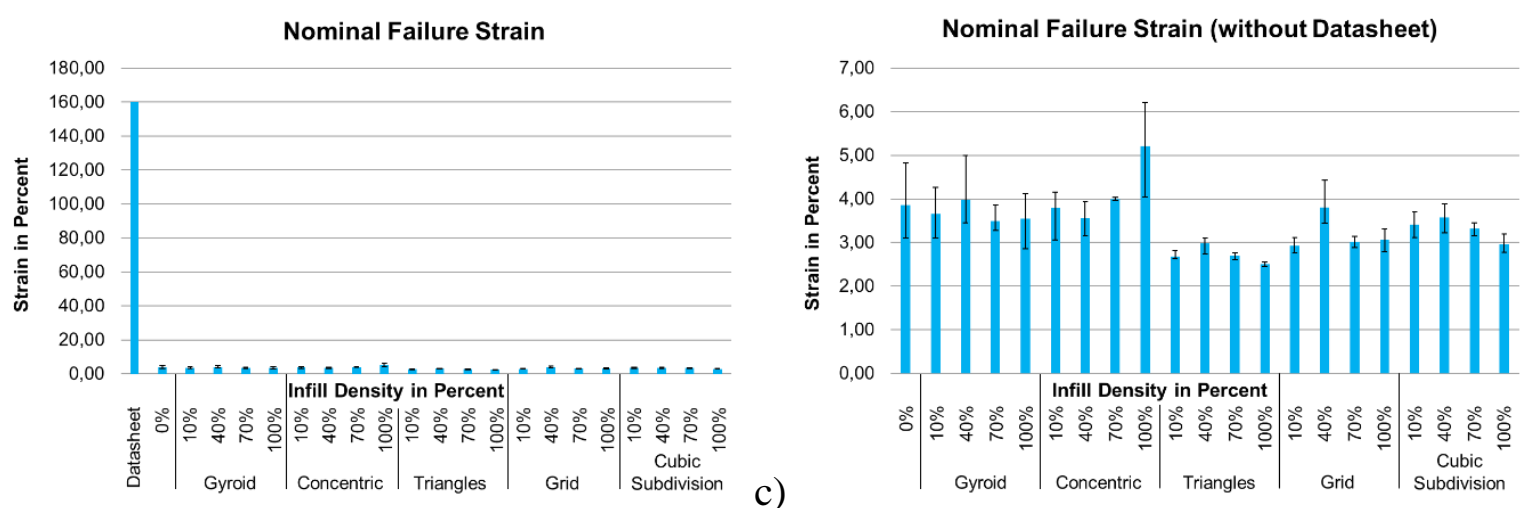

d)

Source: Own

Fig. 3: Result diagrams of the mean values for a) specific Young's modulus, b) specific tensile strength, c) nominal failure strain with data sheet values and d) nominal failure strain without data sheet values

\subsubsection{Specific Tensile Strength}

The tensile strength indicates the maximum load that can be applied to the specimen before it starts to fail.

The tensile strength values show results similar to those for the Young's modulus. There is also a linear rise with an increasing infill density, as well as differences at the same infill density with a better performance of the concentric structure.

Compared to the values of the data sheet, however, the test results are significantly lower and reach only about $50 \%$.

\subsubsection{Nominal Failure Strain}

Failure strain characterizes the deformation capacity of a material until failure due to fracture, which is also referred to as ductility. 
The difference to the data sheet becomes particularly obvious in respect of the failure strain values. According to the manufacturer, the homogeneous microstructure of the injectionmolded specimen achieved a failure strain of $160 \%$. In contrast, the investigations presented here only resulted in values between $2 \%$ and $4 \%$ ! They are, however, not uncommon and remain within the range of values also found in literature $[11,12]$. This also applies to the values of the Young's modulus and tensile strength. For the investigated structures, no tendency with increasing infill density can be detected for fracture strain. The values rather seem to be independent of the infill density and are at a specific level for the respective structures. Only for the concentric structure, the failure strain also increases with higher infill rates. However, the data vary widely around their mean value, which can lead to misinterpretation. This is caused by production-related variations in the quality of specimens.

\section{Discussion}

The results observed in this examination reveal three influencing factors that determine the mechanical properties.

For both the Young's modulus and the tensile strength, a linear growth of the values could be observed with an increasing infill density. This applies to all the structures studied. The rising infill density also leads to an increase in the load-bearing cross-section of the specimens, which means that more load is required for deformation. Thus, if the infill density reaches $100 \%$, values that are comparable with the data sheet are achieved.

The manufacturing process used determines the resulting microstructure in the specimen. The microstructure is, in turn, the main parameter that influences the mechanical properties. Figure 4 shows the fracture points of a specimen with $40 \%$ concentric (a) and $40 \%$ grid structure (b).

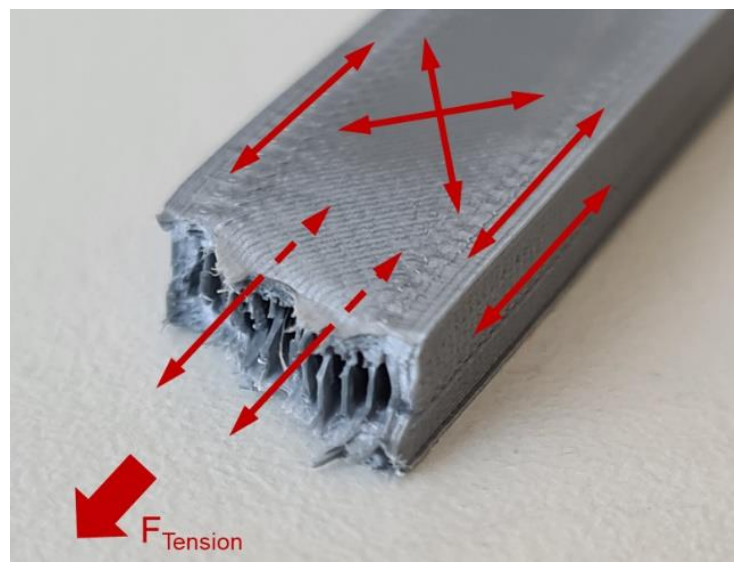

Source: Own

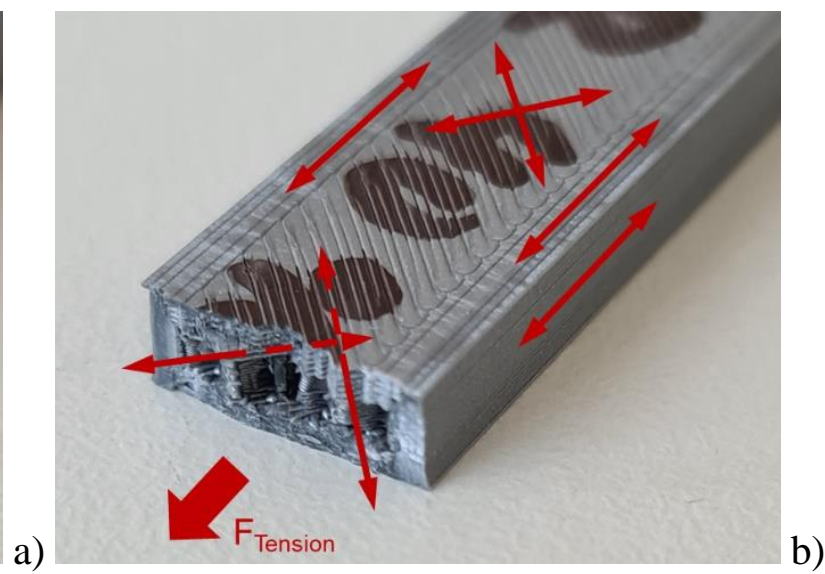

Fig. 4: Images of the fracture faces of a tensile specimen with a) $40 \%$ concentric structure and $b) 40 \%$ grid structure

Due to the path of the print head during manufacture, different deposition directions of the filament line occur within the component. In the concentric structure, all the constituents are arranged in the tensile direction of the specimen, as are the lateral faces of the specimen. Only the top and bottom faces show a $45^{\circ}$ angle to the tensile direction. Here, the majority of the filament lines are loaded in their deposition direction and over the entire cross-sectional area (see Figure 5a). This results in significantly higher values for the Young's modulus and tensile strength, which is also reported by other authors [7]. In the specimen with grid structure, only the side faces are arranged in the tensile direction of the specimens. The infill structure as well as the top and bottom faces are at a $45^{\circ}$ angle to the tensile direction. In this 
case, only a small part of the filament lines is loaded in the deposition direction, however, most of them at an angle of $45^{\circ}$. This has an impact on the load-bearing cross-section of the specimens since it is reduced to the contact areas between the individual filament lines, as illustrated in Figure 5b. The better performance of the concentric structure is therefore related to the position of the filament lines in the direction of loading. The lower values for tensile strength are likewise due to the existing microstructure. Even when favorably positioned with respect to the loading direction, the inhomogeneity caused by the layered structure reaches only $50 \%$ of the values of a homogeneous specimen.

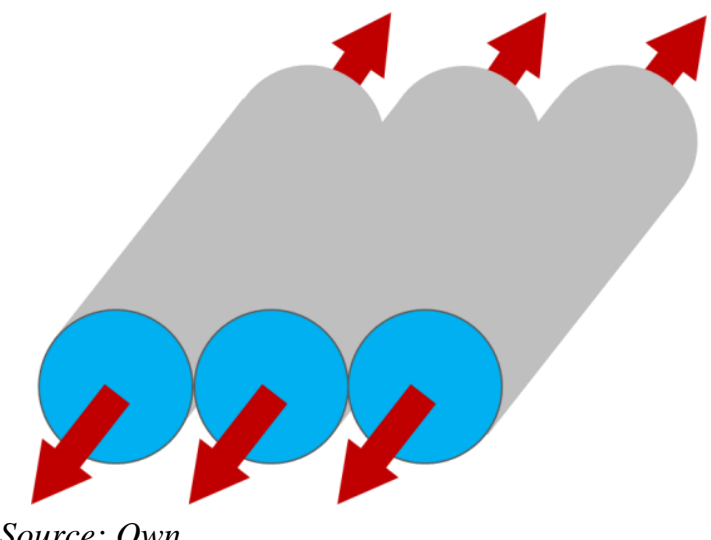

a)

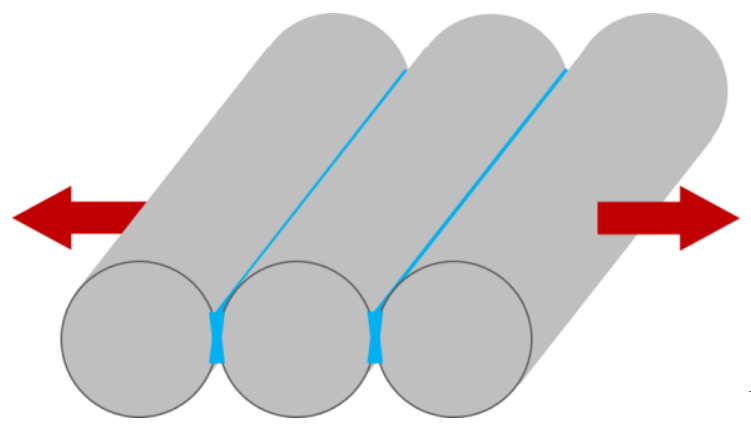

b)

Fig. 5: Schematic representation of a) loading in the direction of deposition and b) at an angle up to $90^{\circ}$ to the direction of deposition

The behavior of the fracture strain can also be attributed to the prevailing microstructure. Due to the inhomogeneity compared to the injection molded specimens, only a fraction of the values indicated in the data sheet are achieved. As it can be seen in the macro images of the fracture faces in Figure 6a, the favorable position with respect to the loading direction also increases the deformability of the specimen, resulting in ductile fracture, which is well visible in the fibrous structure of the fracture face. The unfavorable position of the filament lines with respect to the loading direction in Figure 6b, on the other hand, leads to reduced deformability and brittle fracture behavior since the filament lines detach from each other. A smooth or scaly fracture face is recognizable. Once filament separation begins, it continues along the contact area throughout the specimen, leading to sudden failure.
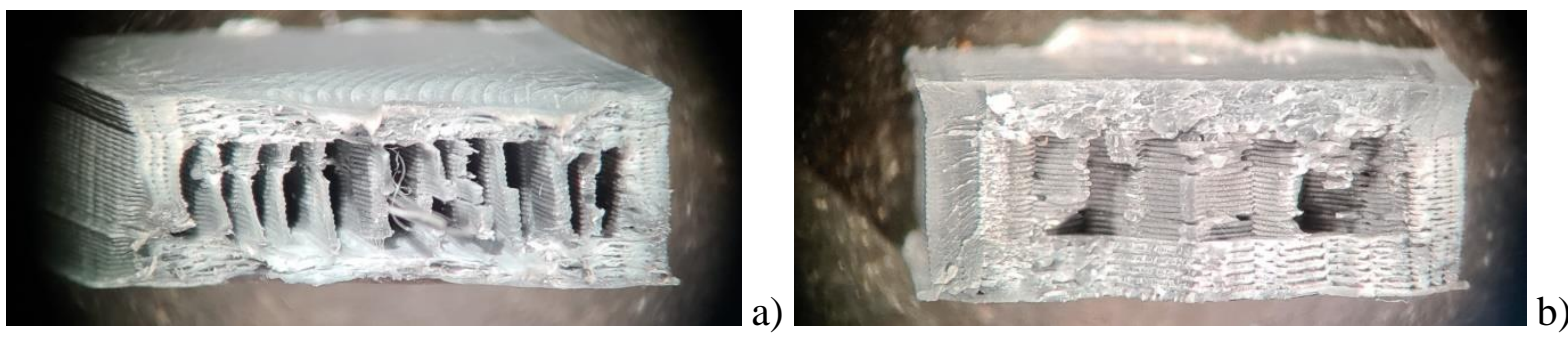

Source: Own work

Fig. 6: Macro images of the fracture faces of a tensile specimen with a) $40 \%$ concentric structure and $b) 40 \%$ grid structure

Structures with a high filament content that are loaded in the direction of deposition also achieve higher fracture strain values, e.g. in the case of gyroid and concentric. Triangles, grids and cube subdivision are, on the other hand, structures where the filaments are loaded at an angle of up to $90^{\circ}$ to the direction of deposition, resulting in lower fracture strains. The influence of the infill density can be neglected in this respect. 


\section{Conclusion}

In summary, a linear relationship between the infill density and the Young's modulus as well as the tensile strength can be stated. This applies to all structures under investigation. At the same time, it has been noted that the Young's modulus is influenced by the structures and infill densities and does not represent a pure material parameter.

Furthermore, the applied manufacturing process determines the resulting microstructure, which, in turn, significantly influences the mechanical properties. Different deposition directions of the filament lines during the manufacturing process lead to a dependence of the mechanical properties on the tensile direction to the position of the filament lines. The best results are achieved if the tensile direction is in the direction of deposition since the loadbearing cross-section is at its maximum in this case. When positioned at an angle of up to $90^{\circ}$ to the direction of deposition, the load-bearing cross-section is reduced to the connection between the individual filament lines. The fracture strain does not show a significant dependence on the infill density or structure.

\section{Acknowledgements}

We would like to thank the European Regional Development Fund (EFRE) for financial support in the implementation of the F3D project and Prof. Dr. F. Deckow and Dr. M. Rößler from University of cooperative education (Berufsakademie Sachsen - Staatliche Studienakademie Glauchau) for the administrative support.

Special thanks are extended to the co-authors as well as Dr. C. Eßbach and D. Fischer for their support in preparing this paper, conducting the investigations, and discussing the results.

\section{Literature}

[1] AlAFAGHANI, A.; QATTAWI, A.; ALRAWI, B.; GUZMAN, A.: Experimental Optimization of Fused Deposition Modelling Processing Parameters: A Design-forManufacturing Approach. Procedia Manufacturing. DOI: $\underline{10.1016 / j . p r o m f g .2017 .07 .079}$

[2] LUZANIN, O.; MOVRIN, D.; PLANCAK, M.: Effect of layer thickness, deposition angle, and infill on maximum flexural force in FDM-built specimens. Journal for Technology of Plasticity. 2014, Vol. 39, Issue 1, pp. 49-57. ISSN 0354-3870.

[3] ALAFAGHANI, A.; QATTAWI, A.: Investigating the effect of fused deposition modeling processing parameters using Taguchi design of experiment method. Journal of Manufacturing Processes. DOI: 10.1016/j.jmapro.2018.09.025

[4] FERNANDEZ-VICENTE, M.; CALLE, W.; FERRANDIZ, S.; CONEJERO, A.: Effect of Infill Parameters on Tensile Mechanical Behavior in Desktop 3D Printing. 3D Printing and Additive Manufacturing. DOI: 10.1089/3dp.2015.0036

[5] JOHNSON, G. A.; FRENCH, J. J.: Evaluation of Infill Effect on Mechanical Properties of Consumer 3D Printing Materials. Advances in Technology Innovation. 2018, Vol. 3, Issue 4, pp. 179-184. ISSN 2415-0436. e-ISSN 2518-2994.

[6] RODRÍGUEZ-PANES, A.; CLAVER, J.; CAMACHO, A. M.: The Influence of Manufacturing Parameters on the Mechanical Behaviour of PLA and ABS Pieces Manufactured by FDM: A Comparative Analysis. Materials. DOI: $\underline{10.3390 / \mathrm{ma1} 1081333}$ 
[7] RISMALIA, M.; HIDAJAT, S. C.; PERMANA, I. G. R.; HADISUJOTO, B.; MUSLIMIN, M.; TRIAWAN, F.: Infill pattern and density effects on the tensile properties of 3D printed PLA material. Journal of Physics: Conference Series. DOI: $\underline{10.1088 / 1742-6596 / 1402 / 4 / 044041}$

[8] PANDZIC, A.; HODZIC, D.; MILOVANOVIC, A.: Effect of Infill Type and Density on Tensile Properties of PLA Material for FDM Process. In: Katalinic, B. (ed.), Proceedings of the $30^{\text {th }}$ DAAAM International Symposium on Intelligent Manufacturing and Automation. DAAAM International, Vienna, Austria, 2019, pp. 0545-0554. ISBN 978-3-902734-22-8. ISSN 1726-9679. DOI: 10.2507/30th.daaam.proceedings.074

[9] CHACÓN, J. M.; CAMINERO, M. A.; GARCÍA-PLAZA, E.; NÚÑEZ, P. J.: Additive manufacturing of PLA structures using fused deposition modelling: Effect of process parameters on mechanical properties and their optimal selection. Materials \& Design. DOI: $\underline{10.1016 / j . m a t d e s .2017 .03 .065 ~}$

[10] SUKINDAR, N. A. B.; ARIFFIN, M. K. A. B. M.; BAHARUDIN, B. T. H. T. B.; JAAFAR, C. N. A. B.; ISMAIL, M. I. S. B.: Analysis on the impact process parameters on tensile strength using 3D printer repetier-host software. ARPN Journal of Engineering and Applied Sciences. 2017, Vol. 12, Issue 10, pp. 3341-3346. ISSN 18196608.

[11] KOTLINSKI, J.: Mechanical properties of commercial rapid prototyping materials. Rapid Prototyping Journal. DOI: 10.1108/RPJ-06-2012-0052

[12] LANZOTTI, A.; GRASSO, M.; STAIANO, G.; MARTORELlI, M.: The impact of process parameters on mechanical properties of parts fabricated in PLA with an opensource 3-D printer. Rapid Prototyping Journal. DOI: 10.1108/RPJ-09-2014-0135

Dipl.-Ing. Wolfgang Förster; Prof. Dr. Thomas Pucklitzsch; Prof. Dr.-Ing. habil. Daniela Nickel 


\section{VLIV RŮZNÝCH VÝPLŇOVÝCH STRUKTUR NA MECHANICKÉ VLASTNOSTI V PŘÍDAVNÉ VÝROBĚ}

Kromě vnějšího pláště nejvíce přispívají k mechanické integritě aditivně vyráběné součásti vnitřní struktury. Za účelem zkoumání vlivu geometricky odlišných vnitřních struktur a hustoty výplně byly na Youngově modulu pružnosti $v$ tahu a deformaci při přetržení připraveny vzorky kyseliny polymléčné (PLA) pomocí modelování fúzního nanášení a testovány při pokojové teplotě. Významný vliv na mechanické vlastnosti měla hustota výplně, výrobní proces a výsledná mikrostruktura. Stručně řečeno, poloha mikrostruktury vzhledem ke směru zatížení byla shledána jako významný faktor vlivu.

\section{EINFLUSS VERSCHIEDENER INNENSTRUKTUREN AUF DIE MECHANISCHEN EIGENSCHAFTEN IN DER ADDITIVEN FERTIGUNG}

Neben der äußeren Hülle haben die Innenstrukturen den größten Anteil an der mechanischen Integrität eines additiv gefertigten Bauteils. Um den Einfluss der geometrisch verschiedenen Innenstrukturen und Füllgrade auf Elastizitätsmodul, Zugfestigkeit und Bruchdehnung zu untersuchen, wurden Zugproben aus Polylactid (PLA) mit dem Schmelzschichtverfahren hergestellt und bei Raumtemperatur geprüft. Es konnte ein signifikanter Einfluss des Füllgrades, des Fertigungs-verfahrens und der resultierenden Mikrostruktur auf die mechanischen Eigenschaften beobachtet werden. Zusammenfassend zeigt sich dabei die Lage der Mikrostruktur zur Belastungsrichtung als maßgeblicher Einflussfaktor.

\section{WPŁYW RÓŻNYCH STRUKTUR WYPEŁNIAJĄCYCH NA MECHANICZNE WŁAŚCIWOŚCI W PRODUKCJI ADDYTYWNEJ}

Oprócz zewnętrznej obudowy na integralność mechaniczną w największym stopniu wpływają addytywnie wytwarzane elementy struktury wewnętrznej. W celu zbadania wpływu zróżnicowanych geometrycznie struktur wewnętrznych i gęstości wypełnienia na Moduł Younga, określający sprężystość przy rozciąganiu i ściskaniu, były w momencie zerwania metodą modelowania uplastycznionym tworzywem (FDM) przygotowane próbki polikwasu mlekowego (PLA), które badano w temperaturze pokojowej. Znaczący wpływ na właściwości mechaniczne miała gęstość wypełnienia, proces produkcji oraz końcowa mikrostruktura. Podsumowując, wykazano, że położenie mikrostruktury w stosunku do kierunku obciążenia jest ważnym czynnikiem decydującym. 